\title{
Threats posed by Asian subterranean termites in the Fiji Islands and their potential controls: a review
}

\author{
Ravneel R. Chand ${ }^{1, *}$, Anjeela D. Jokhan ${ }^{2}$, Harshna Charan², Kushaal Raj ${ }^{1}$ and Priyatma Singh ${ }^{1}$ \\ ${ }^{1}$ School of Science and Technology, University of Fiji, Lautoka, Fiji Islands. \\ ${ }^{2}$ Faculty of Science, Technology and Environment, University of the South Pacific, Fiji Islands. \\ ${ }^{*}$ Corresponding author: s11074077p@gmail.com
}

\begin{abstract}
Termites belong to the infraorder Isoptera, which contains almost 3,000 described species worldwide. These social insects cause substantial damage globally leading to billions of dollars of losses annually. Damage can occur to timber, wooden goods, paper, cotton, certain plastics, trees and many crops. Consequently, termite control and management is a major sector in the global pest-control industry. However, economic losses due to termite damage have not been quantified in the Fiji Islands to date. A review of published literature was conducted to assess the geographic range of Asian subterranean termites that occur in the Fiji Islands and to identify existing and potential control measures. The most common termite species that is known to cause millions of dollars of damage each year in the Fiji Islands is Coptotermes gestroi. This species is currently controlled primarily using the chemical fipronil but integrated termite management is the preferred long-term solution. Other possible control methods include physical, cultural, chemical and biological options.
\end{abstract}

Keywords Asian subterranean termite, Coptotermes gestroi, biology and status, management practices, Fiji Islands.

\section{INTRODUCTION}

Termites play important roles in the natural functioning of the environment (Jembere et al. 2017). They improve the physiochemical properties of soil by building mounds, which enhance fertility (Jouquet et al. 2006; Jembere et al. 2017; Lee 2017). However, of the 3000 termite species known worldwide, 183 species $(6.1 \%)$ are considered to be 'pests' and 83 species (2.8\%) cause severe damage to wooden structures (Edwards \& Mill 1986; Rust \& Su 2012). According to Rust and Su (2012), the cost of control and repairs associated with subterranean termites was approximated at around US\$ 32 billion worldwide in 2010. Approximately US\$ 1 million of that occurs in the Fiji Islands annually (Biosecurity Authority of Fiji 2017). The most economically important and the most aggressive of the subterranean termites belong to the genus
Coptotermes (Kuswanto et al. 2015).

The Asian subterranean termite, Coptotermes gestroi mainly affects wooden construction materials and is considered a structural and building pest worldwide (Roszaini et al. 2009; Evans et al. 2013; Harit et al. 2014; Ahmad et al. 2015). Control of C. gestroi is difficult due to underground nesting habits of this species, which makes colonies difficult to locate (Nunes \& Nobre 2001; Hassan et al. 2008). Optimal colony growth has been largely attributed to food availability, high humidity and warm temperatures (Harit et al. 2016). For example, the wood consumption rate of $C$. gestroi has been found to be higher at $35^{\circ} \mathrm{C}$ than at $15-30^{\circ} \mathrm{C}$ (Cao \& Su 2016). Increase in temperature (possibly as a result of climate change) may allow C. gestroi to become more widespread in the Pacific in the future. During 2009-2010, an El Niño event occurred that 
resulted in reduced rainfall in the Fiji Islands, which may have provided favourable foraging conditions for the termite colonies, and this could be a reason that $C$. gestroi has become abundant in the Fiji Islands since then. To support this, Santos et al. (2010) reported that the foraging activity of $C$. gestroi was negatively correlated with relative humidity, soil moisture and rainfall. This paper provides a review on the C. gestroi (Asian subterranean termite), because they are a serious pest of wooden structures, timber products and other lignocellulosic materials in most of the tropical regions (Sornnuwat 1996; Husseneder 2010). We focus on the current $C$. gestroi management practices in the Fiji Islands.

\section{METHODS}

A literature search using the terms 'Asian subterranean termites' OR 'termites as pests in the Fiji Islands was undertaken in November 2017. A total of 39 relevant articles, 6 reports and 21 other supporting documents (such as book sections, news and conference papers) were found and analysed.

\section{RESULTS AND DISCUSSION}

\section{Termite species In the Fiji Islands}

Fourteen termite species are known to occur in the Fiji Islands: Cryptotermes brevis, Cryptotermes domesticus, Glyptotermes brevicornis, Glyptotermes taveuniensis, Incisitermes repandus, Procryptotermes sp., Neotermes gnathoferrum, Neotermes papua, Neotermes samoanus, Coptotermes acinaciformis, Prorhinotermes inopinatus, Nasutitermes sp., Nasutitermes olidus, and Coptotermes gestroi (Asian subterranean termite). The first 13 species in this list are "endemic" to the Fiji Islands. In contrast, C. gestroi is exotic and is likely to have been introduced from Asia or the United States 20-30 years ago, probably through infested shipping pallets (Ministry of Information Fiji 2010). This species is native to South East Asia and has spread to Florida, USA (Scheffrahn 2013), the Caribbean and Brazil (Su et al. 1997). The Asian subterranean termite is the second most destructive subterranean termite in the world; the most destructive termite being Coptotermes formosanus (Lee et al. 2009).

\section{Status of C. gestroi in the Fiji Islands}

The occurrence of C. gestroi was noted in the Fiji Islands in 2009 when many homes in the Western division of Viti Levu were infested. The Fijian government contracted a Queensland forestry entomologist to identity the species of termite that was causing massive damage to wooden houses and crops in Lautoka. The species was identified as C. gestroi (Prasad 2013). Millions of dollars of damage have been caused by this termite (Biosecurity Authority of Fiji 2017). The Fijian Government spent about 3 million dollars to control C. gestroi from 2009 to 2011 (Biosecurity Authority of Fiji 2017). This cost included the treatment of damage housing structures, school building and vegetation, re-treatment and rehabilitation of infested structures and running awareness workshops for the local community (Prasad 2013). As part of the treatment plan, the Fijian Government (through the Biosecurity Authority of Fiji (BAF)) undertook an intensive biosecurity operation (Operation Kadivuka) that was launched in 2010 to eradicate Asian subterranean termites from the country. The operation involved three phases: Phase 1 included a survey and awareness in termite infested area; Phase 2 involved containing the spread of termite colonies through repair and treatment of infested houses and trees; and Phase 3 focused on the control of termites through monitoring and surveillance of affected areas and applying preventive measures where necessary. At the end of 2011, a total of 865 termite-infested houses and around 20 termite-damaged schools had been repaired by the Kadivuka operation (Biosecurity Authority of Fiji 2017).

\section{Biology of Asian subterranean termite}

Dispersal flights or "swarms" of C. gestroi occur at dusk or at night during which large numbers of alates leave the colony. In the Fiji Islands, termite swarming usually occurs towards the end of the year, from October onwards (Biosecurity Authority of Fiji 2017). Porch lights, indoor 
lights, and video monitors often attract alates inside, particularly when doors and unscreened windows are left open (Scheffrahn \& Su 2000). The presence of large numbers of alates indoors usually indicates infestation of the structure. Generally, the alates that do enter buildings die from desiccation as they are unlikely to find the moist wood/soil substrates necessary for successful colonisation.

Coptotermes gestroi build their nests underground. They generate social colonies that have a well organised caste system, which includes reproductive, soldiers and workers (Tian \& Zhou 2014). The role of the reproductives is to lay the eggs. There is typically one pair of primary reproductives per colony; the king and the queen (Tian \& Zhou 2014). A queen has an average life span of about 20 years and can lay 1,000 eggs a day. One termite colony can have between 60,000 and 1 million termites (The Terminix International 2017).

Worker termites are milky or cream coloured in appearance unlike the soldier caste. They have smaller, saw-toothed mandibles than the soldiers (Fig. 1), which allows them to take small bites of wood and to carry building materials (Scheffrahn $\&$ Su 2000; Korb 2008). As their name suggests, the workers do most of the work in the colony; digging tunnels, gathering food and caring for the young. They also feed the king, queen and soldiers, who are unable to feed themselves. Workers and soldiers are sterile (Korb 2008).

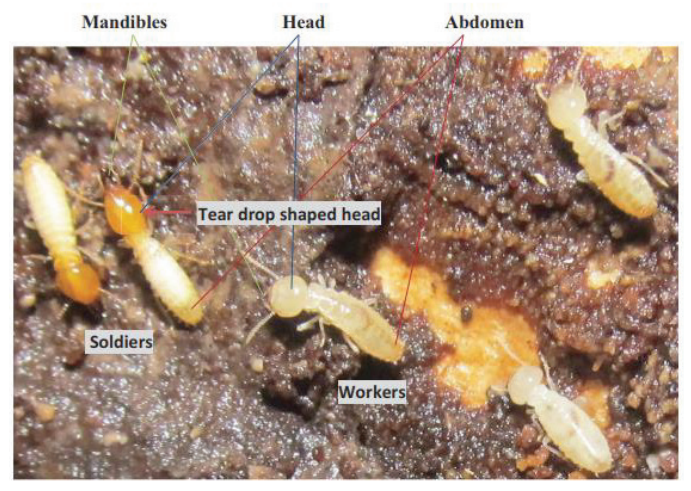

Figure 1 Coptotermes gestroi workers and soldiers (Prasad 2013).
Coptotermes gestroi, like all subterranean termites, must have moisture to survive and $C$. gestroi is specifically limited to more tropical localities (Scheffrahn \& Su 2017), where there is high humidity. Coptotermes gestroi like to live in dark, damp and moist places they typically tunnel through the soil, which provides an excellent source of moisture.

These termites can also survive on moisture from leaks (roof and plumbing), air conditioning condensation, and wall veneers that are installed below grade (below ground level) (Staunton 2014).

\section{Termites as pests of crops in the Fiji Islands}

A wide range of crops such as sugarcane, rice, cassava, yam, cottons, maize and coconuts in the Fiji islands (as well as the other tropical countries) are affected by termites due to their voracious appetite for plant materials (cellulose) and even for the non-cellulosic materials such as electric cables (Rouland-Lefèvre 2011; Biosecurity Authority of Fiji 2017). For instance, in several South Pacific countries, Neotermes rainbowi termites attack coconut palms, hollowing out and establishing colonies in trunks, which often leads to the collapse of trees (Redford et al. 2013). Agricultural damage has occurred both directly by $C$. gestroi damaging the crops and reducing yield, and indirectly, with termites interfering with the farming infrastructures (buildings and fencing) and destroying containers of shipping products. Many farmers have raised concerns in regards to the decrease in crop yields resulting from termite infestation in Lautoka corridor, Fiji Islands (Nasilasila 2014). However, there has not been much work done in quantifying the damages resulting from termite infestation in agriculture especially in the Fiji Islands and hence this may be an avenue for future research.

In addition, the use of chemicals has led to many environmental issues and as a result, few chemicals such as organochlorine and organophosphate insecticides are now prohibited in certain countries (Barlow et al. 2015). Nonchemical approaches such as the application of fertilisers, crop rotation, deep tillage and early 
harvesting may not offer assurance in terms of protecting crops for a longer period (RoulandLefèvre 2011). Beyond this, an integrated control strategy may alleviate the many concerns raised over the use of chemicals in the environment and is possibly the most suitable strategy to be utilised in management of termites (Su \& Scheffrahn 2000; Rouland-Lefèvre 2011).

\section{Common management practices for Coptotermes gestroi}

\section{Chemical control}

Chemical control of C. gestroi is associated with infusing the wood with synthetic or natural chemicals to kill or repel C. gestroi (Ahmed et al. 2004; Bobbarala \& Vadlapudi 2009). Bark powder extracts from Rhizophora apiculate mixed with ethyl acetate have been found to show a strong anti-termite activity against C. gestroi (Abdul Khalil et al. 2009). Various chemicals known to have insecticidal activity such as, pyrethroids, bifenthrin, permethrin, cypermethrin, deltamethrin, chlorfenapyr, imidacloprid, fipronil and various organophosphate compounds have been applied to soil as a conventional technique to control termite abundance (Scheffrahn et al. 1997; Riekert \& Van den Berg 2003). Treating substrates with pyrethroid insecticides repels termites and reduces penetration into wood. The mechanisms of insecticidal activity vary among different types of chemicals but a range of chemicals provide an effective protection of structures from subterranean termites when applied. However, wood treated with cypermethrin 10 EC (retention of $0.166 \mathrm{~kg} /$ cubic $\mathrm{m}$ ) was found to display visible surface damage caused by termites and did not lead to $100 \%$ termite mortality within 4 weeks (Pongpattananurak 1997). In contrast, treatment of wood blocks with a boron compound (retention of $3.28 \mathrm{~kg}$ / cubic $\mathrm{m}$ ) resulted in termites losing $8.77 \%$ body mass and wood blocks treated with greater than of $2.08 \mathrm{~kg} /$ cubic m resulted in $100 \%$ mortality within 4 weeks (Pongpattananurak 1997). A combination of permethrin (2.0\%), alphacypermethrin $(0.3 \%)$, and bifenthrin $(0.1 \%)$ solutions has been found to be effective against C. gestroi when mixed with soil (Sornnuwat et al. 1996; Roszaini et al. 2009). Long-term protection (12 months) using Silafluofen and Fenvalerate at $2 \%$ treatment of wood has also been found to be effective (Sornnuwat et al. 1996; Roszaini et al. 2009). Polymerisation of wood with tributyltin acrylate (TBTA) or modification by acetylation improved resistance against $C$. gestroi to some extent in laboratory testing (Ibach et al. 2000).

In the Fiji Islands, $C$. gestroi is widely controlled by a product called Termidor (BASF, Germany) that contains fipronil (100 g/L) as the active ingredient. It is applied by dusting or in bait stations, and an average of $2-3$ vials of termiticide are used to treat a building (Prasad 2013; Biosecurity Authority of Fiji 2017).

\section{Physical Control Methods}

The use of physical barriers is gaining momentum worldwide as a method of preventing attacks from C. gestroi on structures (Grace 1996). Physical controls in the form of stainless-steel screens or mesh barriers (e.g. TERMI-MESH 1, TMA Corporation, Australia) have been utilised because they protect against the foraging activities of the Coptotermes genus of termites (Grace \& Yates 1999). However, if mesh is not installed properly, then termites are able to enter and forage (Ahmed 2000; Ahmed et al. 2004). Other commonly used physical barriers include: crushed rock, high-grade stainless steel (solid-sheet material), sand, glass, basalts and aluminium. These physical barriers act as mechanical barriers that prevent termite penetration and damage to buildings. The use of graded materials (like sand, basalts, stainless steel mesh) with a range of sizes is based on principle that small particles or gaps hinder the passage of termites to pass through. For instance, almost half the particles in coarse sand are $1.4-1.8 \mathrm{~mm}$ in diameter and almost another quarter are $<1.4$ $\mathrm{mm}$, which makes this material an effective barrier. Likewise, small mesh is difficult for termites to bite through (Yates et al. 1997; Grace \& Yates 1999).

According to Specialist Termite Control 
(2014), coarse material can also be combined with chemical control by impregnating it with an insecticide (such as deltamethrin and/or bifenthrin) to create a combination of a toxic zone and a physical barrier. Other physical methods of termite control include; heat, electricity, cold, freezing and microwaves (Doi et al. 1999; Tagbor 2009; Hansen et al. 2011). Passing high voltage of electricity through infested wooden materials can be used to electrocute any termites present (Lewis \& Haverty 2001). Similarly, the use of a cold treatment that involves the pumping of liquid nitrogen into infested areas and freezing it to below $-7^{\circ} \mathrm{C}$ is also effective. Such methods can only be applied to a small area (Scheffrahn \& Su).

Other methods of termite control include: destruction of mounds, removal of the queen, flooding mounds with water, use of hot ash and pepper (Dufera \& Fufa 2014). Infestations can be prevented by adopting good construction techniques, such as using water-proof materials or barriers because C. gestroi breed best in wet wood. Yates et al. (1997) recommended: "(1) avoiding any contact between wood and the soil, (2) keeping structural wood dry and controlling moisture conditions beneath and around the structure, and (3) ensuring that portions of the structure that are prone to insect attack can be readily inspected". This could be a reason why the prevalence of termites in the Fiji Islands mostly occurred largely in rural and semi-rural areas of the country where buildings did not meet Occupational Health and Safety requirements (Biosecurity Authority of Fiji 2017). In the Fiji Islands, cultural control involves burning of wood so that termites lose their wings and are not able to fly away to reproduce (Chaudhary 2011; Biosecurity Authority of Fiji 2017).

\section{Biological Control}

Biological control constitutes a more environmental friendly approach to termite management compared to chemical control measures (Culliney \& Grace 2000). Fungi, nematodes, ants and Trojan termites as well as natural products such as volatiles from seeds, bark, leaves, fruit, roots, wood and resin have been used for biological control (Mauldin \& Beal 1989; Epsky \& Capinera 1998; Culliney \& Grace 2000; Verma et al. 2009). The fungus Isaria farinose has been found to cause $95 \%$ termite mortality under laboratory conditions (Lopes et al. 2017). The entomophathogenic fungi Metarhizium anisopliae and Beauveria bassiana are highly effective against most species of termites, especially C. gestroi, by resulting in complete mortality (Lai 1977; LeBayon et al. 1999; Rath 2000; Engler \& Gold 2004; Neves \& Alves 2004). Metarhizium anisopliae has been found to be more effective than other fungi such as Beauveria bassiana against termites in general (Rath 2000; Lenz et al. 2005). Metarhizium anisopliae works best when incorporated with baiting matrix and has been commercially produced as Bioblast ${ }^{\mathrm{TM}}$ to control subterranean termites (Lenz et al. 2005). According to Maketon et al. (2007), there was a $100 \%$ mortality of C. gestroi after one month when the conidial suspension spray $\left(3 \times 10^{8}\right.$ condidia $\left./ \mathrm{mL}\right)$ and baited method were used. Microbial insecticides can be low cost if virulent strains are available and these can be germinated in vitro. Wooden stakes infested by an unidentified basidiomycetous fungus were repellent to C. gestroi under laboratory conditions (Peralta et al. 2003). However, the application of fungi to timber and dwellings for effective pest management has yet to be studied.

Control of termites using entomopathogenic fungi has proven unsuccessful in the Fiji Islands (Prasad 2013; Biosecurity Authority of Fiji 2017) possibly because of termite grooming, isolation of infected colony members and difficulty in obtaining pathogens due to their cryptic habitat (Osbrink et al. 2001). Nematodes of families Steinernematidae and Heterorhabditidae have also been used for the biological of subterranean termites (Trudeau 1989; Lenz et al. 2000). However, control by nematodes in the Fiji Islands is in its very early stages, and the nematode profile of Fijian soil is not well known so information still remains scarce. Therefore, much research is needed to further develop nematode control of C. gestroi in the Fiji Islands. Coptotermes gestroi has been controlled by Trojan termites where 
infected termites are introduced to a colony and the toxins are distributed throughout the colonies due to colony aggression and grooming behaviour (French 1991). This technique requires termites such as Coptotermes lacteus 'Trojan termite' to be coated with arsenic trioxide and then released to the locations of other termites such as $C$. acinaciformis. Hence, there is an aggressive behaviour between the two species and spreading the toxins to the pest causing mortality. However, this is a very costly method, which would be difficult to adopt on a larger scale and knowledge remains limited on this technique for use on C. gestroi (French 1991).

\section{Integrated Termite Management (ITM)}

Integrated termite management has arisen in order to develop a sustainable model by improving communication between stakeholders, developing sufficient biological information about termite species, standardising inspection of affected areas and implementing correct action plans meticulously (Snyder 1927; Forschler 2011). According to Ahmed et al. (2004), approaches to termite control are increasingly adopting ITM practices by using a number of strategies such as chemical and physical barriers, combinations of dust toxicants and baits, and treated timber to 'build out termites' and ensure whole-house protection.

The combined monitoring-baiting programme proposed by Su and Scheffrahn (1998) could possibly be employed as an ITM approach for termite control in the Fiji Islands. Monitoring stations to detect termites are placed in the soil surrounding a structure. Once termites are found in the stations, monitoring devices are replaced with slow-acting baits such as the insect-growth regulator, hexaflumuron (which inhibits synthesis of the chitin exoskeleton of termites). The slowacting nature of the toxicant allows for termites to socialise with the colonies thereby infesting the colony members and the non-repellent nature does not deter the termites from ongoing feeding (Kard 2003; Vreysen et al. 2007; Evans et al. 2013). A combination of monitoring and baiting has the advantage of requiring only small amounts of termiticide as opposed to the soil technique where termiticide is in the environment for a longer period of time (Sornnuwat et al. 1996; Scheffrahn et al. 1997). For instance, use of a combined monitoring-baiting procedure demonstrated that 4-1500 mg hexaflumuron (insect growth regulators) can potentially reduce the foraging population of subterranean termites, while a barrier treatment of a single house could use $5-10 \mathrm{~kg}$ of Termidor (Su 1994). Hence, this combined method is a cost-effective approach to control termites. Bait is toxic, slow acting and non-repellent; therefore, it can be considered an effective approach, especially if combined with another biological and/or chemical agent(s) such as chlorpyrifos, permethrin, cypermethrin and fenvalerate (Su \& Scheffrahn 1998; Tsunoda 2005) and/or incorporates a data-management system. For instance, Prolinx ${ }^{\mathrm{TM}}$ is a data-tracking tool that can be used to dictate station placement, improve monitoring efficiency and predict baiting requirement or other optional control tools for different environmental conditions. Hence integrated programmes may become selfimproving and cost-effective systems through the use of feedback from such tools.

Physical barriers may replace the use of liquid insecticides for soil treatment in future and the use of such barriers installed before building construction can complement the monitoring and baiting programme to reduce damage caused by termites. The information obtained from a data-management system can be used to improve monitoring efficiency and predict bait requirements or alternative control methods based on environmental factors (Su \& Scheffrahn 1998). Other methods such as chemical, physical and biological control can be used in combination to create an effective management technique (Su \& Scheffrahn 1998; Kard 2003). For instance, $\mathrm{Su}$ and Scheffrahn (2000) highlighted that the combination of soil barriers, monitoring/ baiting stations and localised treatments as an effective ITM approach. The barrier treatment aimed to exclude subterranean termites from the structures while the monitoring and baiting approach provided the termite 
population control. Such ITM systems are not fully implemented in the Fiji Islands however the chemical formulation Termidor (active termiticide ingredient fipronil) is used in the forms of baiting and dusting. The cost associated with Termidor use and building repair in the Fiji Islands is estimated up to $\$ 8,000$ for some houses (Prasad 2013). According to the International Plant Protection Convention (2010), the BAF has consolidated collaboration efforts with other ministries to prevent the contamination outside infested boundary. The BAF also believes that ITM approach is the best long-term solution for controlling Asian subterranean termites through proper technical expertise and collaboration with external and internal parties. Hence, the success of ITM mainly depends on a holistic knowledgebased systematic plan that is generated from intense inspection/monitoring combined with information on the bio-ecology of termites (Mahapatro \& Chatterjee 2018).

\section{CONCLUSION}

Termites are perhaps some of the most destructive social insects worldwide. A range of control strategies for subterranean termites have been examined in a number of countries and generally involves the use of physical, cultural, chemical, biological and/or integrated termite management methods. The Fiji Islands experienced an outbreak of the Asian Subterranean termites Coptotermes gestroi in late 2009 and early 2010 (mainly in Lautoka) that resulted in massive losses costing millions of dollars in structural damage to affected homes and schools. Control of C. gestroi is difficult because of its cryptic underground nesting habits, which make colonies difficult to locate. At present, control of C. gestroi in the Fiji Islands is generally conducted by the BAF using the commercial product Termidor; however, Termidor is an expensive chemical imported from Australia. The biological control of termites with nematodes and fungi remain uncertain due to limited information available on soil profiles (such as $\mathrm{pH}$, temperature, moisture and ability of compounds to be held by the soil particles). Integrated termite management is considered the best approach to controlling this pest species in the future because it is a proactive option. It is being used on a commercial scale in other parts of the world but is yet to be utilised fully in the Fiji Islands. The overall success of any control method depends on early detection and proper identification of termites as well as a general awareness by (and support of) the public in understanding the problem at hand. In the Fiji Islands, physical barriers and baiting could be incorporated together to prevent further C. gestroi infestation even if ITM is not fully implemented.

\section{ACKNOWLEDGEMENTS}

The authors would like to acknowledge the Biosecurity Authority of Fiji (BAF) for their support in terms of providing relevant information for the following review article.

\section{REFERENCES}

Abdul Khalil HPS, Kong NH, Ahmad MN, Bhat AH, Jawaid M, Jumat S 2009. Selective solvent extraction of the bark of Rhizophora apiculata as an anti-termite agent against Coptotermes gestroi. Journal of Wood Chemistry and Technology 29(4): 286-304.

Ahmed BM 2000. The effects of boron-treated timbers against Coptotermes species in Australia, $\mathrm{PhD}$. Unpublished thesis, University of Melbourne, Victoria.

Ahmed B, French J, Vinden P 2004. Review of remedial and preventative methods to protect timber in service from attack by subterranean termites in Australia. Sociobiology 44(2): 1-13.

Ahmad I, Kuswanto E, Dungani R 2015. Threat of subterranean termites attack in the asian countries and their control: a review. Asian Journal of Applied Sciences 8(4): 227-239.

Barlow SM, Sullivan FM, Miller RK 2015. Occupational, industrial and environmental agents. Drugs during pregnancy and lactation (3rd edition). San Diego, Academic Press. Pp. 599-638.

Biosecurity Authority of Fiji 2017. Asian Subterranean Termites. Retrieved 04/11/2017 
from www.baf.com.fj/news/asiansubterranean-termites.

Bobbarala V, Vadlapudi V 2009. Abrus precatorius L. seed extracts antimicrobial properties against clinically important bacteria. International Journal of PharmTech Research 1: 1115-1118.

Cao R, Su N-Y 2016. Temperature preferences of four subterranean termite species (Isoptera: Rhinotermitidae) and temperature-dependent survivorship and wood-consumption rate. Ecology and Population Biology 109(1): 6471.

Chaudhary F 2011 (3 October). Termites hold up traffic. The Fiji Times.

Culliney T, Grace J 2000. Prospects for the biological control of subterranean termites (Isoptera: Rhinotermitidae), with special reference to Coptotermes formosanus. Bulletin of Entomological Research 90(1): 9-21.

Doi S, Kurimoto Y, Ohmura W, Ohara S, Aoyama M, Yoshimura T 1999. Effects of heat treatments of wood on the feeding behaviour of two subterranean termites. Holzforschung 53(3): 225-229.

Dufera JT, Fufa TG 2014. Evaluation of chemical, botanical and cultural managements of termites control. Pakistan Journal of Biological Sciences 17(2): 272-276.

Edwards R, Mill AE 1986. Termites in buildings. Their biology and control. East Grinstead, England, Rentokil Ltd.

Engler KM, Gold RE 2004. Effects of multiple generations of Metarhizium anisopliae on subterranean termite feeding and mortality. National Conference on Urban Entomology.

Epsky ND, Capinera JL 1998. Efficacy of the entomogenous nematode Steinernema feltiae against a subterranean termite, Reticulitermes tibialis (Isoptera: Rhinotermitidae). Journal of Economic Entomology 81: 1313-1317.

Evans TA, Forschler BT, Grace JK 2013. Biology of invasive termites: a worldwide review. Annual Review of Entomology 58: 455-74.

Forschler B 2011. Sustainable termite management using an integrated pest management approach. In: Dhang $\mathrm{P}$ ed.
Urban pest management: An environmental perspective, Oxfordshire: CAB International. Pp. 133-144.

French JRJ 1991. Baits and foraging behavior of Australian species of Coptotermes. Sociobiology 19: 171-186.

Grace JK 1996. Termite-resistant construction: use of a stainless steel mesh to exclude Coptotermes formosanus. Sociobiology 28(3): 365-372.

Grace JK, Yates JR 1999. Termite resistant construction and building materials. In: Robinson WH, Rettich F, Rambo GW ed. 3rd International Conference on Urban Pests, Czech University of Agriculture, Prague, 1922 July 1999. Pp. 399-406.

Hansen J, Johnson J, Winter D 2011. History and use of heat in pest control: a review. International Journal of Pest Management 57(4): 267-289.

Harit AK, Gajalakshmi S, Abbasi SA 2014. Swarming of the termite Coptotermes gestroi in North-Eastern Puducherry. Zoology and Ecology 24(1): 62-69.

Harit AK, Gajalakshmi S, Abbasi SA 2016. Studies on the development of captive termite colonies. Zoology and Ecology 26(4): 301312.

Hassan A, Hafiz A, Rashid M 2008. Minimum perimeter treatment against subterranean termites (Isoptera: Rhinotermitidae) using imidacloprid in Malaysia. 6th International Conference on Urban Pests, Budapest, Hungary, 13-16 July 2008. Pp. 373-378.

Husseneder C 2010. Symbiosis in subterranean termites: a review of insights from molecular studies. Environmental Entomology 39(2): 378-388.

Ibach RE, Hadi YS, Nandika D, Yusuf S, Indrayani Y 2000. Termite and fungal resistance of in situ polymerized tributyltin acrylate and acetylated Indonesian and USA wood.The International Research Group on Wood. [Preservation. Section 3, Wood Protecting Chemicals: 31st annual meeting, Kona, Hawaii, USA, 14-19 May 2000. Stockholm, Sweden : IRG Secretariat, 2000]. 13 p. 
International Plant Protection Convention 2010. Asian subterranean termite (Coptotermes gestroi) incursion FJI-01/2. 1-5.

Jembere A, Berecha G, Tolossa AR 2017. Impacts of termites on selected soil physicochemical characteristics in the highlands of Southwest Ethiopia. Archives of Agronomy and Soil Science 63(12): 1676-1684.

Jouquet P, Dauber J, Lagerlof J, Lavelle P, Lepage M 2006. Soil invertebrates as ecosystem engineers: Intended and accidental effects on soil and feedback loops. Applied Soil Ecology 32: 153-164.

Kard BM 2003. Integrated pest management of subterranean termites (Isoptera). Journal of Entomological Science 38(2): 200-224.

Korb J 2008. The ecology of social evolution in termites. In: Korb J, Heinze J ed. Ecology of Social Evolution. Berlin, Heidelberg, Springer Berlin Heidelberg. Pp. 151-174.

Kuswanto E, Ahmad I, Dungani R 2015. Threat of subterranean termites attack in the Asian countries and their control: a review. Asian Journal of Applied Sciences 8(4): 227-239.

Lai PY 1977. Biology and ecology of the Formosan subterranean termite, Coptotermes formosanus, and its susceptibility to the entomogenous fungi, Beauveria bassiana and Metarrhizium anisopliae, Ph.D. Unpublished thesis, University of Hawaii, Honolulu, Honolulu.

LeBayon I, Ansard D, Brunet C, Paulmier I, Pruvost A 1999. Biocontrol of Reticulitermes santonensis by entomopathogenic fungi. International Research Group on Wood Protection, IRG Secretariat, Stockolm. Pp. 1-9.

Lee KC, Sun J-Z, Zhu Y, Mallette EJ 2009. A case study of the Formosan subterranean termite, Coptotermes formosanus (Isoptera: Rhinotermitidae) transported with a noncellulosic commercial carrier in south Mississippi. Sociobiology 53(3): 619-629.

Lee S-H 2017. Effects of tunnel slopes on movement efficiency and behavior of termites. Oriental Insects: 1-10.

Lenz M, Lee C, Robinson W 2005. Biological control in termite management: the potential of nematodes and fungal pathogens. Proceedings of the Fifth International Conference on Urban Pests (ICPU), Suntec, Singapore. July 10-13, 2005. Pp. 47-52.

Lenz M, Kamath M, Lal S, Senivasa E 2000. Status of the tree-damaging Neotermes sp. Fijis American mahogany plantation and preliminary evaluation of the use of entomopathogens for their control. ACIAR Small Project No. FST/96/205, Project Report (in part).

Lewis VR, Haverty MI 2001. Lethal effects of electrical shock treatments to the western drywood termite (Isoptera: Kalotermitidae) and resulting damage to wooden test boards. Sociobiology 37(1): 163-184.

Lopes RdS, Lima Gd, Correia MTdS, da Costa AF, Lima EÁdLA, Lima VLdM 2017. The potential of Isaria spp. as a bioinsecticide for the biological control of Nasutitermes corniger. Biocontrol Science and Technology 27(9): 1038-1048.

Mahapatro GK, Chatterjee D 2018. Integrated termite management in the context of indoor and outdoor pest situation. In: Khan MA, Ahmad W eds. Termites and Sustainable Management: Volume 2 - Economic Losses and Management. Cham, Springer International Publishing. Pp. 119-135.

Maketon M, Sawangwan P, Sawatwarakul W 2007. Laboratory study on the efficacy of Metarhizium anisopliae (Deuteromycota: Hyphomycetes) in controlling Coptotermes gestroi (Isoptera: Rhinotermitidae). Entomologia Generalis 30(3): 203-218.

Mauldin JK, Beal RH 1989. Entomogenous nematodes for control of subterranean termites, Reticulitermes spp. (Isoptera: Rhinotermitidae). Journal of Economic Entomology 82: 1638-1642.

Ministry of Information Fiji 2010. Government taskforce to counter termite outbreak. In: Ministry of Communications ed. Fiji Islands, The Fijian Government, http://www.fiji.gov.fj/ Media-Center/Press-Releases/Governmenttaskforce-to-counter-termite-outbreak.aspx. 
Nasilasila V 2014 (31 December). Farmer discovers termites affecting sugarcane yield. Fiji Sun Online.

Neves PMOJ, Alves SB 2004. External events related to the infection process of Cornitermes cumulans (Kollar) (Isoptera: Termitidae) by the entomopathogenic fungi Beauveria bassiana and Metarhizium anisopliae. Neotropical Entomology 33: 51-56.

Nunes L, Nobre T 2001. Strategies of subterranean termite control in buildings. In: Lourenço PB, Roca P ed. Historical Constructions. Brasil.

Osbrink WLA, Williams KS, Connick WJ, Wright MS, Lax AR 2001. Virulence of bacteria associated with the Formosan subterranean termite (Isoptera: Rhinotermitidae) in New Orleans, LA. Environmental Entomology 30(2): 443-448.

Peralta RCG, Menezes EB, Carvalho AG, Aguiar-Menezes E 2003. Feeding preference of subterranean termites for forest species associated or not a wood decaying fungi. Floresta e Ambiente 10: 58-63.

Pongpattananurak N 1997. Resistance of wood preservative-treated Rubberwood to the subterranean termite. Retrieved 12/05/2018 from http://agris.fao.org/agris-search/search. do? recordID $=$ TH2000000681

Prasad R 2013. Potential of the problematic weed Abrus precatorius to control invasive Coptotermes gestroi termites in Fiji, MSc. Unpublished thesis, University of the South Pacific, Fiji Islands.

Rath AC 2000. The use of entomopathogenic fungi for control of termites. Biocontrol Science and Technology 10(5): 563-581.

Redford A, Walters T, Howard FW, Trice M 2013. Termites(Isoptera).Retrieved12/05/2018from http://idtools.org/id/palms/sap/factsheet. php? name $=$ Termites $+\% 28$ Isoptera $\% 29$

Riekert HF, Van den Berg J 2003. Evaluation of chemical control measures for termites in maize. South African Journal of Plant and Soil 20(1): 1-5.

Roszaini K, Rafeadah R, Dahlan JM 2009. Durability of Malaysian timbers against the Asian subterranean termite Coptotermes gestroi Wasmann. Journal of the Institute of Wood Science 19(1): 16-21.

Rouland-Lefèvre C 2011. Termites as pests of agriculture. In: Bignell DE, Roisin Y, Lo N ed. Biology of termites: a modern synthesis. Dordrecht, Springer Netherlands. Pp. 499517.

Rust MK, Su N-Y 2012. Managing social insects of urban importance. Annual Review of Entomology 57: 355-375.

Santos MN, Teixeira MLF, Pereira MB, Menezes EB 2010. Environmental factors influencing the foraging and feeding behavior of two termite species (Isoptera: Rhinotermitidae) in natural habitats. Sociobiology 55(3): 763778.

Scheffrahn RH 2013. Overview and current status of non-native termites (Isoptera) in Florida. Florida Entomologist 96: 781-788.

Scheffrahn RH, Su N-Y 1997. Drywood termite control: weighing all the options. Ft. Lauderdale REC Research Report 971. University of Florida Wood-Destroying Insects Unit. http://entomology.ifas.ufl.edu/ creatures.

Scheffrahn RH, Su NY 2000. Common name: Asian subterranean termite scientific name: Coptotermes gestroi (= havilandi) (Wasmann) (Insecta: Isoptera: Rhinotermitidae), University of Florida, USA Retrieved 15/12/2017 http://entomology.ifas.ufl.edu/ creatures/urban/termites/havilandi.htm

Scheffrahn RH, Su NY 2017. Asian Subterranean Termite, Coptotermes gestroi (=havilandi) (Wasmann) (Insecta: Isoptera: Rhinotermitidae). Retrieved 15/01/2017 http://edis.ifas.ufl.edu/pdffiles/IN/IN28500. pdf

Scheffrahn RH, Su NY, Busey P 1997. Laboratory and field evaluations of selected chemical treatments for control of drywood termites (Isoptera: Kalotermitidae). Journal of Economic Entomology 90: 492-502.

Snyder TE 1927 . Termites modify building codes. Journal of Economic Entomology 20(2): 316321.

Sornnuwat Y 1996. Studies on damage of 
constructions caused by subterranean termites and its control in Thailand. Wood research : bulletin of the Wood Research Institute Kyoto University 83: 59-139.

Sornnuwat Y, Vongkaluang C, Takahashi M, Yoshimura T, Tsunoda K 1996. Longevity of soil termiticides weathered for 3-4 years in Thailand under in situ observation and laboratory bioassay using Coptotermes gestroi Wasmann. Mokuzai Gakkaishi 42: 520-531.

Specialist Termite Control 2014. Phyisical termite protection barriers, ST control, Austrialia Retrieved 18/10/2017 http://www. termitespecialist.com.au/information-forbuilders/physical-barriers/

Staunton I 2014. Urban pest management in Australia. 5 ed. Sydney, UNSW Press. 358 p.

Su N-Y 1994. Field evaluation of a hexaflumuron bait for population suppression of subterranean termites (Isoptera: Rhinotermitidae). Journal of Economic Entomology 87(2): 389-397.

Su N-Y, Scheffrahn RH 1998. A review of subterranean termite control practices and prospects for integrated pest management programmes. Integrated Pest Management Reviews 3(1): 1-13.

Su N-Y, Scheffrahn RH 2000. Termites as pests of buildings. In: Abe T, Bignell DE, Higashi M ed. Termites: evolution, sociality, symbioses, ecology. Dordrecht, Springer Netherlands. Pp. 437-453.

Su NY, Scheffrahn RH, Weissling T 1997. A new introduction of a subterranean termite, Coptotermes havilandi Holmgren (Isoptera: Rhinotermitidae) in Miami, Florida. Florida Entomologist 80: 408-411.

Tagbor TA 2009. The anti-termite properties and basic phytochemicals of eight local plants and the chemical characterisation of Thevetia peruviana (pers) K. Schum in Ghana. Unpublished thesis, Kwame Nkrumah University of Science and Technology, West Africa. 1-237 p.

The Terminix International Co. Ltd. 2017. How termite colonies are formed. Memphis, TN, USA. https://www.terminix.com/termite- control/colonies/

Tian L, Zhou X 2014. The soldiers in societies: defense, regulation, and evolution. International Journal of Biological Sciences 10(3): 296-308.

Trudeau D 1989. Selection of entomophilic nematodes for control of the eastern subterranean termite, Reticulitermes flavipes (Kollar) (Isoptera: Rhinotermitidae). Unpublished thesis, University of Toronto, Toronto. $238 \mathrm{p}$.

Tsunoda K 2005. Improved management of termites to protect Japanese homes. UK, International Conference on Urban Pests (ICUP). Pp. 33-37.

Verma M, Sharma S, Prasad R 2009. Biological alternatives for termite control: A review. International Biodeterioration \& Biodegradation 63(8): 959-972.

Vreysen MJB, Robinson AS, Hendrichs J, Kenmore P 2007. Area-Wide Integrated Pest Management (AW-IPM): Principles, Practice and Prospects. In: Vreysen MJB, Robinson AS, Hendrichs J eds. Area-Wide Control of Insect Pests: From Research to Field Implementation. Dordrecht, Springer Netherlands. Pp. 3-33.

Yates III J, Grace J, Tamashiro M 1997, April. The Formosan subterranean termite: a review of new management methods in Hawaii. Proceedings of FAOPMA convention held in Hong Kong. Pp. 59-68. 